\title{
Classified Research and the Open University
}

\author{
James A. Roberts
}

Vice Provost for Research

The University of Kansas

$\mathrm{N}$

ot long ago, I-and others-spent more time than I wanted reviewing a proposal from a new faculty member that was clearly in violation of The University of Kansas classified research policy. The name of the proposal was "The KILL Missile System." The title alone raised a red flag, because KU has a prohibition on conducting research with intended results that could destroy or incapacitate human life.

We at KU have been talking about our classified research policy for some time, as I think colleagues at many institutions are, and faculty governance is considering a revised policy. We have looked at other universities' classified research policies, and I have to admit that KU's current policy may be the most convoluted of them all. There is a history behind that, as I am sure there is on most campuses. But there must be a way to find a simple, non-convoluted way of dealing with this issue.

In this paper, I discuss the term "classified research." To do so, I relate the discussion to the overdone practice of simplifying an issue by collapsing a number of complex questions into a single black-and-white question. I also want to comment on what some other universities are doing regarding classified research and then propose a simplified classified research policy that addresses the major issues of concern in conducting university research today.

\section{Framing the questions}

It is always good to look back to the nation's founders for wisdom. I am struck by something Thomas Jefferson wrote in 1820 about the founding of the University of Virginia: "This institution will be based on the illimitable freedom of the human mind. For here we are not afraid to follow truth wherever it may lead, or to tolerate any error so long as reason is left free to combat it." 1

With that as an institutional research policy, what would Jefferson have to say today about the University of Virginia, for example, conducting classified research? What might Jefferson say about the whole notion of classification? Scientists including Edward Teller were opposed to classification. While we could have a philosophical debate about the practice of classification, that is not the discussion here. In this paper we are taking as a given that there is information

1. Letter to Thomas Jefferson to William Roscoe, 27 December 1820. L\&B 15.303 
to which the federal government or nongovernmental organizations restrict and control access. So this is not about classification per se but rather dealing with it as it exists.

In attempting to frame the question and develop a policy, one is hindered by a problem that clouds the issue: the collapsing of a complex set of questions into a single question to be answered "yes" or "no." Take global warming as an example. This issue has become so politicized that every aspect of the set of questions related to global warming has been collapsed into one question with an answer that is almost in the realm of belief or non-belief. In fact, there are many questions: by how much is the climate actually warming, whether it is short-term or long-term, what are the causes and the cures, etc. But today you are either for global warming or against it, period.

In the same way, while the topic of classified research embraces multiple questions, classified research policies often reflect this collapsing of the issue. What is needed is to deal with classified research as a single question, in the true sense of the word, and then tease out the other questions contained in the term.

\section{Classified research issues}

My insight into this issue is rooted in the 20 years of my career spent working on national security projects in places that required a high-level security clearance. Classified research presents several thorny issues for universities:

- Philosophical opinions

- Publication restrictions

- Practicality and cost
- Academic freedom

- Harm to students' educational progress

Philosophically, we have the following questions:

- Should an institution engage in research when some or all of the research material/results cannot be released to the general public?

- Should a university directly support the military/industrial complex, conduct embryonic stem cell research, etc?

- Should some faculty and students have access to information that others cannot know?

Some are concerned about having research material that cannot be released to the public. Some are concerned about supporting the military/industrial complex. Note that the current KU policy contains a very specific reference that prohibits research that "might involve, for example, the mining of an enemy harbor or the mapping of guerilla locations in a country that is involved in civil war." 2 This language was clearly a reflection of the Vietnam conflict and the time in which the policy was written. But some people also object to conducting embryonic stem cell research. Some are opposed to research using laboratory animals. There may be opposition from some to almost any area of research that one might undertake.

As to restrictions on publication, the Association of American Universities takes the position that member

2. Statement on Classified Research, from The Handbook for Faculty and Unclassified Staff, 17 February 1986. http://www.research.ku.edu/ kucr/policy/comp/class.shtml 
institutions should not accept unlimited scope or time publication restrictions. Most institutions accept this in principle but allow exceptions.

Note that this position does not refer to classified material per se. It is a mistake to assume they are one and the same. It is a mistake to assume that classified means restricted publication in all cases; it is a mistake to assume that unclassified research means unrestricted publication. While there is an automatic assumption that classified material always impedes the ability to publish, I will tell you from my own experience that is not always true. So we have to sort out the real issues to deal with each question. This is the problem with collapsing many questions into one.

Now let us turn to practical matters. What does it mean if someone says, "I want to do classified research?" Does it mean we have to have a security force? Will we need a building with barbed wire around it and 21-year-olds with Uzis standing guard? What other costs are there? Of course there is the question of who pays. And if one ventures into the realm of classified research, there is yet another set of rules from Washington with which to deal.

Other issues involve academic freedom, and the matter of segregating students and faculty into "cleared" and "un-cleared" categories. And there is a serious problem, classified material or not, when we do things that harm a student's progress toward a degree.

\section{So what is classified research?}

In the sense of what "classified" really means, we deal with "classified research" every day at our institutions. An example is private health information. We conduct human subject research where we release general results of the study, but not the details about the participants. Even if someone's specific condition is very interesting, we do not put her name and/or symptoms in a published paper unless she approves. And even then we might not.

There are many things we do not publish. We generalize results, but many other things we keep quiet. We deal with company private material, and that is classified. With survey data, we ask questions of school children but do not release data about specific students. Colleagues cannot read my KU conflictof-interest declaration, nor I theirs.

So how is national security classified information-secret, top secret and above-different? The answer is that it really is not. It simply represents data that cannot be released. Other than the specific sets of rules and the subject matter, a person's answer to a survey question or the wingspan of an advanced military airplane are both restricted, meaning classified per se. The data cannot be released to the public without someone else's approval; to handle the information differently results in trouble.

So what is different? Why does classified research require so much discussion and so many policies? To answer that, we have to break out the real questions that we want to ask. For example, Should the university accept a contract or grant with an unlimited delay of publication? In other words, you may never get to publish without the approval of the sponsor. At $\mathrm{KU}$, we can accept delays up to a certain period of time, but we simply do not accept a grant or 
contract that has an unlimited delay. But that is a different question than whether or not we do research that involves national security.

\section{Other institutions}

What is everyone else doing? Staff in my office did a random check of the published policies of institutions similar to KU but not represented at this conference. (I avoided them because I did not want to engage in a conversation that begins, "Well, our policy doesn't really mean that." That is not the point of the review, since there are always many nuances in practice with all such published policies.) This chart depicts what we found.

\section{University Classified Research Policies}

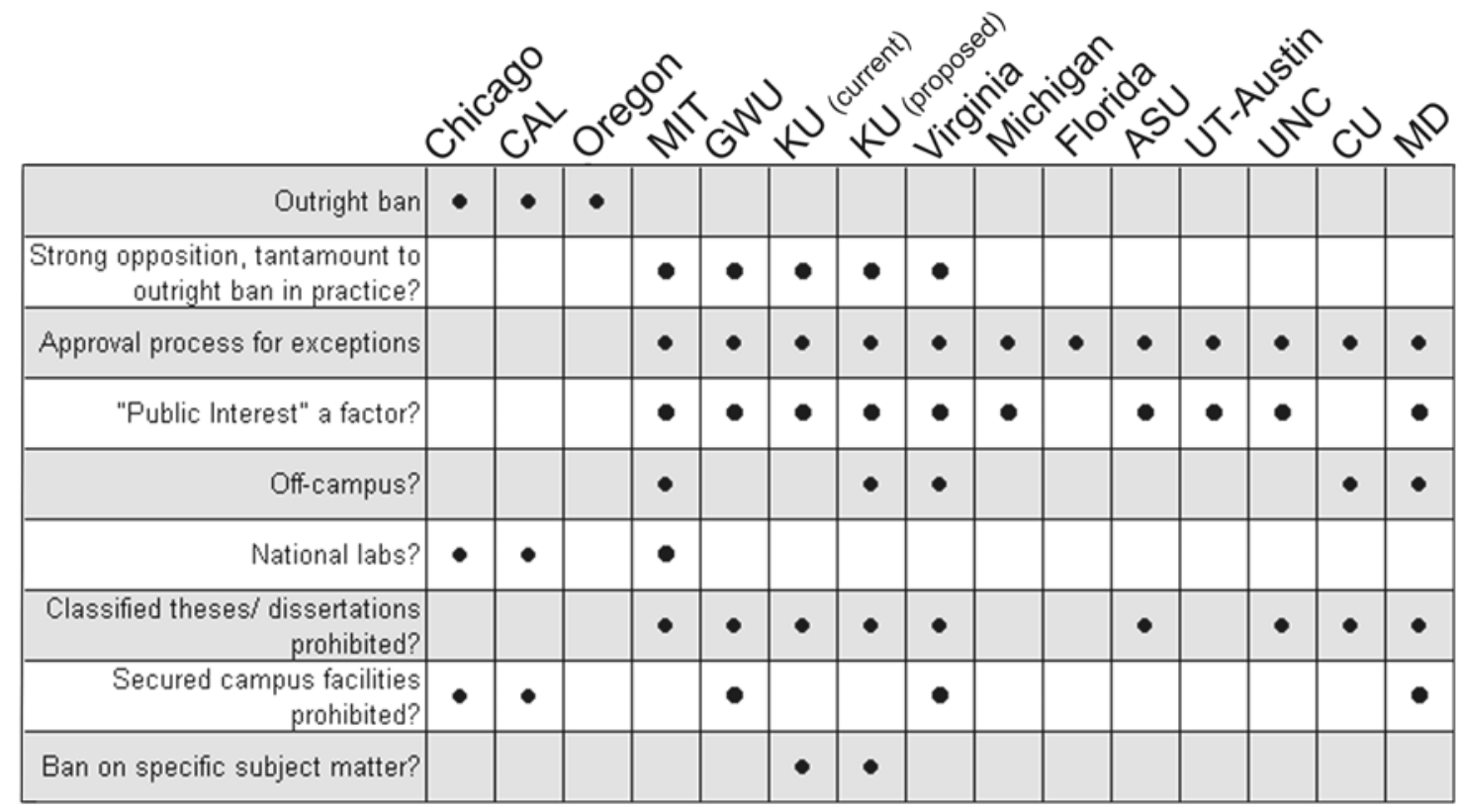

The first three institutions listedUniversity of Chicago, University of California at Berkeley, and University of Oregon-have outright bans on conducting classified research. But both Chicago and Berkeley also say it is okay if you do the research in a national laboratory rather than on campus. We did not include MIT in the group with an "outright ban" even though they state publicly there is one. That is because MIT also says it is permissible to conduct classified research at Lincoln Labora- tories. Thus some of these outright bans have an escape valve.

The second row identifies institutions where there is a strong opposition to classified research but not a ban. Some "We don't allow it, except ..." policies are much stronger than othersalmost requiring the declaration of a national emergency. I list KU twice, because we have a current policy and a proposed policy. (Depending on how the lawyers read the proposed policy, it may move KU into the first row, since the 
intent of the authors is an outright ban on classified research.)

When exceptions are allowed, each institution sets out a process. Most of them cite the national interest or public interest as a reason for engaging in classified research. Some of them say it is permissible to conduct classified research if it is performed off-campus. In fact, the new KU policy says that.

Many of the policies prohibit classified theses and dissertations. It might seem unnecessary to state such a ban, but I have seen and read theses with "top secret" stamped on them, so, again based on my past experience, it is occurring.

Some policies expressly prohibit having a secured facility on campus. Of course a "secured facility" can range from a locked safe to the fenced-in building with the guards with guns. While the latter certainly seems inconsistent with at least my vision of a college campus, a locked safe may not be.

Only one institution in this sample actually banned a particular subject matter, and that institution is KU. We have gone from banning research concerning the mining of Haiphong Harbor in the old policy to banning the intentional harming of humans in the new. Frankly, I think the new proposed policy raises serious questions about stem cell and abortion research, for example. I am disturbed by the possibility of activist groups and others contending that we are violating our own research policy by conducting certain lawful experimentsand they may be right.

\section{A proposal}

I propose a Conduct of Research Policy to replace a Classified Research Policy. In a return to the Jeffersonian ideal, I propose that institutions ought to have a simple statement about academic freedom and research:

\section{Principle I: Free and open inquiry}

The proposed KU policy and this murky issue of subject matter restriction is a real problem. With the "KILL Missile System" proposal, the staff was ready to reject the proposal out of hand not because the faculty member violated the classified research issue, but due to the subject matter issue. In the end, the faculty member's proposal concerned fundamental aerodynamic research, but the wording he initially used was problematic.

This is not the way for a research university to go. Yes, we should obey all federal, state, and local laws. We should abide by appropriate guidelines. But if I am obeying all the rules, why do you have the right to tell me what research to conduct or not? Why do I have the right to tell you what research to conduct or not?

What about dissemination of results? Yes, a university should have a strong statement:

\section{Principle II: Ability to publish}

So should the prohibition on accepting grants and contracts with publication restrictions be absolute? We already allow for delays. But while I agree that universities should have a general policy that they do not accept grants or contracts with unlimited publication restrictions, there has to be wiggle room for the rare 
exception-not the rule, but the rare exception.

\section{Principle III: Specified Process for} Granting an Exception to Principle II

If we grant an exception, then it should be based on a well-defined process. I believe the senior research officer (SRO) and faculty governance, e.g., a standing faculty senate committee, must be involved in such a decision. Then the committee and the SRO should make a recommendation to the provost/chief academic officer.

Why might an exception be granted? Answers to the following questions can provide guidance to making an exception:

- Is this in the nation's best interest?

- Is it in the university's best interest?

- Is it adding value to the student's education?

- Is it adding value to the faculty member's research?

- How much is this going to cost?

In deliberating a proposed exception and in general, I think that there still have to be some outright prohibitions. The overarching principle is:

\section{Principle IV: Protect the students and the campus}

"Secured facilities" should not necessarily be banned, but what I call "top secret facilities" should be. Again "top secret facilities" are the ones with fences around them patrolled by those 21-year-olds with Uzis. "Sorry, not only can you not go in, but you cannot know anything about what is going on in there. And if you try to go in, I am authorized to shoot you."

Note the difference between this and a BSL-3 bio-containment laboratory. The door is locked and you cannot just wander in because you want to, but you are allowed to know what is going on in there. And you won't be threatened with shooting if you stupidly try to go in anyway, but the pathogens inside in fact may threaten your life. In other words, the facility is secured because of the danger posed by the materials in the facility. A top-secret type of facility is against the whole nature of the campus. So I propose

\section{Prohibition IVa: Top secret facilities on campus}

What about off-campus top-secret facilities? I suggest that any work conducted by faculty members requiring such a facility be done through an offcampus corporate facility and a research sub-contract to the university. Or the faculty can simply consult.

If faculty members are going to conduct research involving classified material at a non-university location, then grants and contracts to support this work should be allowed in general, even though they involve classified material.

I do not like the idea of a classified thesis or dissertation. They are contrary to the nature of an academic institution. Thus,

\section{Prohibition IVb: Classified theses and dissertations}

Another problem is ambiguous language. While classified research should not be banned per se, there is a whole realm of ambiguous language that some federal agencies are trying to force on universities. For example, there have been attempts to declare some information "sensitive but unclassified." 
These are the contract provisions we should not accept. We should hold firm to the principle that classification is the means by which the government restricts information.

\section{Prohibition IVc: Accepting sponsored agreements with ambiguous language}

There are sponsored agreements where the sponsor is classified and cannot be revealed. An agreement can also include a classified budget. In other words, a contract itself is stamped "top secret," for example. I see no need to do that in a university environment. It is true that entities negotiating some intellectual property agreements with a university want the agreement to be private. This is a topic for discussion, and perhaps there is a framework in which to work through such issues. In general, though:

\section{Prohibition IVd: Sponsored agreements wherein the agreement itself is classified}

Note that this is different than an unclassified sponsored agreement wherein some of the subject matter of the research is classified.

Finally, and most importantly, we have to ensure that there is no disruption to the educational program of any students involved in the research. Thus:

\section{Prohibition IVe: Disrupting the educational program of a student}

Such disruptions could include a delay in the defense of a thesis or dissertation or the inability to build a publication record.

\section{Example of an exception to the policy}

Say, for example, that there is a proposed sponsored agreement with an unlimited publication restriction. Although not necessarily the case, further assume that this particular agreement involves classified material in the federal government sense. Assume that the university research team that is proposing an exception to the publication restriction policy for this agreement is quite successful and already has a number of other grants and contracts. They represent a big operation, with many faculty members and many students. In their request for an exception, they make the point that there is plenty of material in their portfolio of grants and contracts for all the students' theses and dissertations, and that there will be no completion delays for the students. And they argue that the proposed work will add value. For example, if the students are aerospace engineers, the faculty members argue that the contacts the students make through the proposed work will provide employment opportunities, and the work will give them credentials that will be important for the type of employment that many of them will pursue after completing their degrees.

Suppose further that the faculty members point out that the additional work will actually result in the publishing of more papers related to fundamental research, rather than fewer, even though the specific classified material cannot be published. (Think of research involving human subjects. Just like the protected health information, you do not reveal the wingspan of the particular airplane.) Yes, there may be classified reports generated by the project, but the number of open literature papers will actually increase. Furthermore, the work is important to the national interest, it will increase the 
capability of the research team, and it will enhance the ability of the university to pursue additional research. An exception may be in order and may be in fact a positive for everyone involved.

What if it turns out that a group of researchers begins to abuse the system? They should be dealt with as you would any other faculty member who violates the rules. We should not be creating policies to prevent bad things we think a few bad apples might do and thus restrict the rights of everyone else who plays by the rules. Deal with the bad apples.

\section{Be careful}

We must take care that the exceptions do not become the rule. We do not need a Department of Classified Research. Exceptions really do have to be exceptions. As an institution, we have to be firm with deans, department chairs, and directors on publication expectations. This is one place not to make an exception. Arguing that a faculty member did not publish as much as expected because of conducting research involving classified material should fall on deaf ears. In fact, the opposite should be true.

There could be issues raised about international students, if certain research projects are restricted to American citizens. But we already deal with that. Some fellowships are for American students only. At KU, we accepted a contract that did not involve classified material but did restrict participation to American citizens. In this case, we left the decision to accept or reject the contract up to the PI (who was himself not an American citizen), because there was an ability to submit alien participant names to the sponsor and have them, in effect, "cleared." All the international students whose names were submitted (and the PI) were ultimately approved for participation, and they happily went on with their research. We may not like this, given that in basic research there is frankly no need to exclude international students. We can fight in other venues for doing away with it, but we also do not want to limit the ability of faculty and students to conduct their research. We are seeing more of these restrictions arise, and we will continue to.

\section{Summary}

Don't specifically ban classified research just because it is classified. In fact, don't even use the term "classified research." Don't ban any type of lawful research. Promote an environment that expects quantity and quality of publications from faculty. Carefully define a process for considering exceptions. If there are outliers, use existing policies to deal with bad behavior.

When dealing with classified research policies, there are often many questions that get collapsed into the single "do it or don't do it" question when in fact there are a number of questions to sort out. The "don' $t$ " should really be, "Don't have a classified research policy." Have a "conduct of research" policy. In that policy, adhere to the principles of free and open inquiry of research, to expectation of publication of results, to a clear process for dealing with publication restrictions in sponsored agreements, and to protection of the campus and the students. 